\title{
Dispute Resolution in the Boundaryless Workplace
}

\section{KATHERINE VAN WEZEL STONE*}

Since the Supreme Court's decision Gilmer v. Interstate/Johnson Lane Corp. ${ }^{1}$ which compelled an employee to submit his age discrimination claim to arbitration under the Federal Arbitration Act (FAA), ${ }^{2}$ there has been a dramatic increase in the number of nonunion firms adopting arbitration systems. ${ }^{3}$ At the same time, there has been a flood of lawsuits challenging these employment systems, and a corresponding avalanche of judicial opinions addressing the legal issues left open in Gilmer -issues such as the problematic nature of consent in employment arbitration, the deficiencies in due process, and the applicability of the FAA to employment contracts. ${ }^{4}$ These developments comprise the past and the present of employment arbitration, and were explored at length at the Symposium. This article addresses the future of dispute resolution in the

* Professor of Law and Anne Evans Estabrook Professor of Dispute Resolution, Cornell University. This article was the Keynote Lecture in the Symposium, Gilmer v. Interstate/Johnson Lane Corporation: Ten Years Afier, organized by the Ohio State Journal of Dispute Resolution, Nov. 17, 2000. Portions of this article appeared in Katherine V.W. Stone, The New Psychological Contract: Implications of the Changing Workplace for Labor and Employment Law, 48 UCLA L. REV. 519 (2001). The author would like to thank Alex Colvin for many helpful suggestions and comments.

${ }^{1}$ Gilmer v. Interstate/Johnson Lane Corp., 500 U.S. 20 (1991).

29 U.S.C. $\S \S 1-16$ (1994 \& Supp. 2000).

${ }^{3}$ Katherine V.W. Stone, Employment Arbitration Under the Federal Arbitration Act, in EMPLOYMENT DISPUTE RESOLUTION AND WORKER RIGHTS IN THE CHANGING WORKPLACE 27, 29 (Adrienne E. Eaton \& Jeffrey H. Keefe, eds., 2000) (summarizing studies finding rapid growth in nonunion arbitration) [hereinafter Stone, Employment Arbitration].

${ }^{4}$ See, e.g., Jeffrey W. Stempel, Reconsidering the Employment Contract Exclusion in Section 1 of the Federal Arbitration Act: Correcting the Judiciary's Failure of Statutory Vision, 1991 J. DISP. RESOL. 259 (discussing problematic nature of consent); jean R. Sternlight, Rethinking the Constitutionality of the Supreme Court's Preference for Binding Arbitration: A Fresh Assessment of Jury Trial, Separation of Powers, and Due Process Concerns, 72 TUL. L. REV. 1 (1997) (accord); Stephen J. Ware, Employment Arbitration and Voluntary Consent, 25 HofsTRA L. REV. 83 (1996) (accord); Martin H. Malin, Arbitrating Statutory Employment Claims in the Aftermath of Gilmer, 40 ST. Louls U. L.J. 77 (1996) (discussing deficiencies of due process); Robert A. Gorman, The Gilmer Decision and the Private Arbitration of Public Disputes, 1995 U. ILL. L. REV. 635 (accord); Matthew W. Finkin, "Workers' Contracts" Under the United States Arbitration Act: An Essay in Historical Clarification, 17 BERKELEY J. OF EMPL. \& LAB. L. 282 (1997) (discussing application of FAA to employment disputes). 
workplace. The workplace is changing in ways that make arbitration, as well as other types of dispute resolution, more important than ever. In the changing workplace, it might be possible to design an arbitration system that would help to promote workplace fairness.

\section{THREE CONCEPTIONS OF EMPLOYMENT ARBITRATION}

At present, there are three different conceptions of the role of arbitration in the workplace. Each of these views embodies a distinctive notion about how arbitration systems should be designed and how much the courts should intervene. In the ten years since Gilmer, we have seen an evolution in the attitude of courts from the first to the second of these conceptions. While courts have not yet embraced the third conception, this article urges them to do so.

The first conception is the technique view of arbitration, in which arbitration is valued as a method for resolving conflict that is faster and cheaper than litigation. In this view, arbitration is not a priori superior to other methods of resolving conflict; rather, its goal is to avoid conflict, and its value depends upon the degree to which it accomplishes that goal. This view is outcome agnostic: it says that whether arbitration produces substantive fairness in the outcomes is irrelevant to its value as a resolver of conflict. The technique view counsels courts to order arbitration and enforce awards without regard to the outcomes or to the fairness of the process. However, with its singular focus on conflict avoidance, this view can lead to problematic outcomes. We saw examples of this perspective in some of the early post-Gilmer cases, when courts rubber-stamped the worst forms of cowboy arbitrations, with scant regard for party consent, the fairness of the process, or the justice of the outcome. ${ }^{5}$

Wide sectors of the academic and professional arbitration community criticized the technique view and proposed instead the Due Process Protocol for Mediation and Arbitration of Statutory Disputes Arising Out of the Employment

5 TASK FORCE ON ALTERNATIVE DISPUTE RESOLUTION IN EMPLOYMENT, A DUE PROCESS PROTOCOL FO MEDIATION AND ARBITRATION OF STATUTORY DISPUTES ARISING OUT OF THE EMPLOYMENT RELATIONSHIP (1995), reprinted in DiSP. RESOL. J., Oct.-Dec. 1995, at 37-39, available at http://www.adr.org/education/education/protocol.html (May 9, 2995); e.g., Pony Express Courier Corp. v. Morris, 921 S.W.2d 817 (Tex. Ct. App. 1996) (rejecting unconscionability challenge to arbitration system in which employee had no discovery rights and severely restricted remedies); Lang v. Burlington N. R.R. Co., 835 F. Supp. 1104 (D. Minn. 1993) (enforcing arbitration agreement that had been sent by employer to employee by mail to which employee never consented). See generally Katherine Van Wezel Stone, Mandatory Arbitration of Individual Employment Rights: The Yellow Dog Contract of the 1990s, 73 DENV. U. L. REv. 1017, 1036-41 (1996) [hereinafter Stone, Yellow Dog Contract]. 
Relationship. ${ }^{6}$ The Protocol was drafted by a task force composed of representatives from the American Bar Association, the National Academy of Arbitrators, the Society of Professionals in Dispute Resolution, the National Employment Lawyers Association and other groups who met over time to devise minimum standards of fairness for nonunion employment arbitration procedures. The final document, released in 1995, addresses issues such as arbitral bias, party representation, discovery, and allocation of the cost of arbitration. Organizations that endorsed the Protocol have committed themselves to refusing to participate in arbitrations that do not comply with its due process requirements. ${ }^{7}$

A second conception of arbitration is a public policy view, in which arbitration is seen as a better method for implementing the public policies that are embodied in statutory employment law. In this view, a court should be supportive of arbitration only so long as arbitrators resolve the dispute in a manner that approximates what a court would do in the same case. The public policy view finds support in the language in the Gilmer decision stating that arbitration of statutory rights is permissible so long as it does not entail a loss of "substantive rights."8

The public policy view of arbitration counsels courts to support arbitration so far as arbitration is able to implement public policies, and to police arbitral outcomes to ensure that this has occurred. The public policy view is reflected in some of the recent cases in which courts have refused to enforce arbitral awards that denied employees the remedies that were available under applicable employment law. ${ }^{9}$ A more robust version of the public policy approach would require that courts give extensive judicial review to arbitral outcomes to ensure compliance with substantive law. ${ }^{10}$

${ }^{6}$ Arnold M. Zack, The Evolution of the Employment Protocol, DISP. RESOL. J., Oct.Dec. 1995, at 36, 36.

${ }^{7}$ Stone, Yellow Dog Contract, supra note 5, at 1044.

8 Gilmer v. Interstate/Johnson Lane Corp., 500 U.S. 20, 30-32; see also Mitsubishi Motors Corp. v. Soler Chrysler-Plymouth, Inc., 473 U.S. 614, 628 (1985) (applying arbitration agreement to antitrust claims arising under the Sherman Antitrust Act because "[b]y agreeing to arbitrate a statutory claim, a party does not forgo the substantive rights afforded by the statute").

9 See, e.g., Paladine v. Avnet Computer Techs., 134 F.3d 1054, 1059 (11th Cir. 1998) (stating that for Title VII claims, arbitration must offer "all of the types of relief that would otherwise be available in court."); Martens v. Smith Barney, Inc., 181 F.R.D. 243, 256 (S.D.N.Y. 1998); Armendariz v. Found. Health Psychcare Servs., 6 P.3d 669, 682-83, (Cal. 2000); Ackerman v. The Money Store, 728 A.2d 873, 877 (N.J. Super. Ct. Law Div. 1998).

${ }^{10}$ See, e.g., Robert N. Covington, Employment Arbitration After Gilmer: Have Labor Courts Come to the United States?, 15 HofSTRA LAB. \& EMP. J. 345 (1998); David E. Feller, 
Some courts have moved in the direction of exercising heightened scrutiny of arbitral awards where blatant legal errors have been made by arbitrators. However, if the purpose of judicial review is to ensure enforcement of statutory rights, then the courts should go further and review all rulings on questions of law for their correctness. In addition, courts should require a record to be made of arbitration proceedings and require arbitrators to issue written awards explaining their findings of fact and conclusions of law in order to facilitate effective judicial review. Furthermore, the public policy view might lead us to expect courts to examine the qualifications and training of arbitrators to ensure their ability to effectively enforce statutory claims.

The public policy view is appealing from an aspirational perspective. It posits arbitration as a form of poor man's justice, providing employees with an informal and uncomplicated method for vindicating their legal rights. But the view is difficult to implement. There have been attempts to devise procedures that would approximate a judicial outcome without the cumbersome trappings of a full-blown judicial process, ${ }^{11}$ but they run into difficulties specifying and justifying how much due process protections can be sacrificed without compromising the public policies at stake. ${ }^{12}$ It is difficult to devise an arbitration process that can provide expeditious and inexpensive procedures and yet be just as effective at implementing statutory rights as a court or an administrative agency. Hence the criticism of the public policy view is that it is not possible to fully and correctly implement the public policies embodied in our employment laws without the full panoply of procedural protections available in a civil trial, and without full-blown de novo judicial review of issues of law. ${ }^{13}$

A third view of arbitration is that it is not a mirror image of litigation but rather a method for applying norms and resolving nonjusticiable disputes that arise within a self-regulating, normative community. In the self-regulation view, the distinctive value of arbitration is not that it can enforce laws, but that it can enforce fairness norms that are not presently embodied in law. This view is based on the insight that face-to-face communities generate their own fairness norms

Taft and Hartley Vindicated: The Curious History of Review of Labor Arbitration Awards, 19 BERKELEY J. OF EMPL. \& LAB. L. 296 (1998).

11 See, e.g., Gorman, supra note 4, at 635.

12 Some arbitration procedures that purport to streamline the decision-making process are actually efforts to railroad the outcomes. Stone, Yellow Dog Contract, supra note 5, at 1040.

13 The inability of arbitration to replicate public policy has led some courts to strike down arbitration agreements for certain types of statutory claims. E.g., Duffield v. Robertson Stephens \& Co., 144 F.3d 1182 (9th Cir. 1998) (refusing to require arbitration to decide claims under Title VII because of the perceived inadequacy of arbitration to vindicate the public policies embodied in the discrimination laws.). 
for certain types of situations, and that community elders know and can apply these norms better than a court can.

Traditionally, arbitration has been designed to permit arbitrators to blend internal fairness norms with the norms of the larger community in order to reach results that are neither compelled by the law nor inconsistent with it, but fair in the context of the particular dispute. ${ }^{14}$ Arbitration originated as a form of dispute resolution for use within craft and merchant guilds to resolve disputes between members. These trade groups set their own norms of conduct and business standards, and established their own dispute resolution procedures to resolve disputes that might arise. Disputes that arose often blended allegations of a breach of contract with allegations of violation of customary norms. Arbitrators were expected to resolve them by applying both the parties' own contracts and informal customary norms of the trade. The self-regulation view of arbitration counsels courts to support this aspect of arbitration, when arbitration constitutes and enhances the normative life of the workplace community.

Below.I argue that arbitration can be valuable in the changing workplace from a self-regulation perspective. From such a perspective, arbitration should be used to decide fairness disputes that cannot be litigated nor handled in any other fashion. Because arbitrators can blend internal workplace norms of fairness with statutory law and contractual rights, they can impose accountability, scrutiny, and regularity where it might otherwise be lacking. I give examples of two situations in which arbitration could be useful to resolve disputes over fairness issues that arise in the new workplace. First, I claim that the nature of the new workplace will lead employers to utilize arbitration to provide procedural justice in order to make credible their implicit promises. Second, I describe new types of discrimination disputes that are not cognizable under existing antidiscrimination laws that could be addressed through workplace arbitration. And finally, I make some proposals for the structure of workplace arbitration to avoid the problems of consent, due process, and disregard of substantive rights that have plagued non-union employment arbitration to date. I begin with a description of the new workplace.

\section{UNDERSTANDING THE NEW WORKPLACE}

The workplace is undergoing a major transformation. Employers are moving away from long-term employment relationships and are establishing instead flexible work relations in which individuals are given responsibility for their own careers. In the past, most large corporations organized their workforces into what

${ }^{14}$ Katherine Van Wezel Stone, Rustic Justice: Community and Coercion Under the Federal Arbitration Act, 77 N.C. L. REV. 931 (1999) [hereinafter Stone, Rustic Justice]. 
has been termed an "internal labor market."15 In internal labor markets, jobs were arranged into hierarchical ladders and each job provided the training for the job on the next rung up. Employers who utilized internal labor markets hired only at the entry level, and utilized internal promotion to fill all of the higher rungs. ${ }^{16}$ In this system, employers wanted employees to stay a long time, so they gave them an implicit promise of long-term employment and of orderly and predictable patterns of promotion. Consistent with internal labor market job structures, employers structured pay and benefit systems so that wages and benefits rose as length of service increased. 17

In recent years, employers have dismantled their internal labor market job structures and abandoned the implicit promises of job security that went along with them. In their place, employers are creating new types of employment relationships and new job structures that do not depend upon, or encourage, longevity. ${ }^{18}$ They do this to achieve flexibility, to cross-utilize employees, and to make quick adjustments in production methods as they confront increasingly competitive product markets. Work has thus become contingent, not only in the sense that it is formally defined as short-term or episodic, but in the sense that the attachment between the firm and the worker has been loosened. Some scholars have emphasized the increase in temporary, part-time and other forms of atypical work to describe the increased contingency in the employment relationship. While these types of employment have indeed been growing rapidly, they remain a small portion of the workforce. The more significant change in labor relations concerns the change in the nature of regular, full-time work. The "recasualization of work" has important consequences for the employment relationship, the mutual expectations of employer and employee, and the use of dispute resolution in the workplace.

\section{A. "No Long Term"}

We know a lot about the contemporary workplace from accounts of

${ }^{15}$ See generally PETER B. DOERINGER \& MICHAEL J. PIORE, INTERNAL LABOR MARKETS AND MANPOWER ANALYSIS 13-40 (1971).

16 Katherine Stone, The Origins of Job Structures in the Steel Industry, in LABOR MARKET SEGMENTATION 27 (Richard C. Edwards et al. eds., 1975) [hereinafter Stone, Job Structures].

${ }^{17}$ Katherine Van Wezel Stone, Policing Employment Contracts Within a Nexus-ofContracts Firm, 43 U. TORONTO L.J. 353 (1993).

${ }^{18}$ Katherine V. W. Stone, The New Psychological Contract: Implications of the Changing Workplace for Labor and Employment Law, 48 UCLA L. REV. 519 (2001) [hereinafter Stone, New Psychological Contract]. 
journalists, scholars, and corporate executives. For example, the sociologist Richard Sennett, recently interviewed a number of younger employees about their experiences in the labor market, and reports:

The most tangible sign of that change might be the motto "No long term." In work, the traditional career progressing step by step through the corridors of one or two institutions is withering; so is the deployment of a single set of skills through the course of a working life. ${ }^{19}$

Sennett also quotes an AT\&T executive, who told him, "In AT\&T we have to promote the whole concept of the work force being contingent, though most of the contingent workers are inside our walls. 'Jobs' are being replaced by 'projects' and 'fields of work."'20

The same sentiment was expressed by Jack Welch, the miracle-maker CEO of General Electric Company, who was asked by the Harvard Business Review in 1989, "What is GE's psychologicaI contract with its people?" Welch replied:

Like many other large companies in the United States, Europe, and Japan, GE has had an implicit psychological contract based on perceived lifetime employment. People were rarely dismissed except for cause or severe business downturns, like in Aerospace after Vietnam. This produced a paternal, feudal, fuzzy kind of loyalty. You put in your time, worked hard, and the company took care of you for life. That kind of loyalty tends to focus people inward. But given today's environment, people's emotional energy must be focuséd outward on a competitive world where no business is a safe haven for employment unless it is winning in the marketplace. The psychological contract has to change. ${ }^{21}$

The popular management theorist, Peter Drucker, stated bluntly, "There is no such thing as 'lifetime employment' anymore - such as was the rule in big U.S. or European companies only a few years ago."22 Thomas Davenport, a principle in the leading management consulting firm Towers Perrin, writes, "Has the

19 Richard SENNETt, THE CoRrosion OF ChaRACTER: THE PERSONAL CONSEQUENCES OF WORK IN THE NEW CAPITALISM 22 (1998).

${ }^{20}$ Id., quoted in Edmund L. Andrews, Don't Go Away Mad, Just Go Away; Can AT\&T Be the Nice Guy As It Cuts 40,000 Jobs?, N.Y. TIMES, Feb. 13, 1996, at D6).

${ }^{21}$ Noel Tichy \& Ram Charan, Speed, Simplicity, Self-Confidence: An Interview with Jack Welch, HARV. BUS. REV., Sept.-Oct. 1989, at 112, 120 (emphasis omitted).

22 Peter F. DRUCKer, MANAGNg IN A TIME OF GREAT Change 66-67 (1995) (describing change in composition of temporary workers). 
psychic contract evolved since 1983 ? You bet it has."23

Government data confirms that there has been a dramatic decline in job tenure rates for white males in the past fifteen years. The Department of Labor has collected data on how long employees stay on their jobs since 1983, sorted by gender, age, type of employment, type of establishment, and industry. ${ }^{24}$ This data shows that for men in ages fifty-five to sixty-four, their median years on their current job declined from 15.3 in 1983 to 11.2 in 1998. For men age fortyfive to fifty-four, the decline was from 12.8 to 9.4 . This is precisely the group who were the beneficiaries of the old psychological contract for long-term employment.

In addition, the Department of Labor data on job tenure shows that between 1983 and 1998, there was a significant decline in the number of men who have been with their current employer for ten years or more. For men, ages forty to forty-four, the percent declined from $51 \%$ in 1983 down to $39 \%$ in 1998 . Similar large declines occurred for men in every age group over forty-five. ${ }^{25}$ These are dramatic changes.

The Department of Labor data also shows that for women, there was a slight gain in job tenure until age fifty-five. However, women's job tenure remains far below that of their male counterparts at every step over age twenty. The gains for women reflect women's increasing attachment to the work force-a historical trend since the $1960 \mathrm{~s} .{ }^{26}$ Because women were not generally part of the long-term employment system, their job tenure remains significantly lower than men at every stage. 27

What is driving the change in the nature of the employment relationship? Corporations are restructuring their employment practices in order to meet new production requirements. As firms are forced into a more competitive environment through increased trade and global competition, they have to pay more attention to short-term cost reduction. In addition, the takeover battles in the market for corporate control force firm managers to be responsive to shortterm change in revenues and demand. Part of this responsiveness involves justin-time production, just-in-time product design, and just-in-time workers.

23 Thomas O. DaVenPort, Human CAPTTAL: What IT IS AND Why PEOPLE INVEST IT 26 (1999).

24 Press Release, U.S. Department of Labor Bureau of Labor Statistics, Employee Tenure in 2000 (Aug. 29, 2000) [hereinafter Employee Tenure].

25 Id. at tbl.2.

26 FRANCINE D. BLAU ET. AL., THE ECONOMICS OF WOMEN, MEN AND WORK 113-15 (3d ed. 1998).

${ }^{27}$ Employee Tenure, supra note 25. 


\section{B. The New Psychological Contract}

In restructuring employment practices; management has had to construct what organizational and management theorists call a "new psychological contract" or a "new deal at work."28 The term "psychological contract" refers to an individual's beliefs about the terms of his or her employment contract, an employee's perceptions of the terms of a reciprocal exchange. ${ }^{29}$ The reciprocal nature of the belief distinguishes a psychological contract from mere expectations, which reflect the employee's hopes and aspirations but not the belief in mutual obligation. When expectations are not met, an employee is disappointed; when a psychological contract is breached, the employee feels wronged. ${ }^{30}$ Researchers find that "[f]ailure to honor a contract creates a sense of wrongdoing, deception and betrayal with pervasive implications for the employment relationship."31

The term psychological contract is useful to describe the profound transformation in the employment relationship. One scholar stated the following:

[T]he employer was seen as a caretaker for the employee ... Employees who were good performers were virtually guaranteed a job by their employer until retirement, the employer helped employees plan their careers and provided promotions to ensure career development, and employers were loyal and committed to the job and the organization. In the new psychological contract, both employees and employers have lower expectations for long-term employment, employees are responsible for their own career development, and commitment to the work performed has replaced commitment to the job and organization. ${ }^{32}$

The new employment relationship poses a fundamental paradox: Firms need to motivate employees to provide commitment to quality, productivity, and efficiency while, at they same time, firms are also dismantling the job security

28 Neil Anderson \& Rene Schalk, The Psychological Contract in Retrospect and Prospect, 19 J. ORganizational Behav. 637, 638 (1998); Denise M. Rousseau, The "Problem" of the Psychological Contract Considered. 19 J. ORganizational Behav. 665, 665-68 (1998).

${ }^{29}$ Marcie A. Cavanaugh \& Raymond A. Noe, Antecedents and Consequences of Relational Components of the New Psychological Contract, 20 J. ORGANIZATIONAL BEHAV. 323, 323 (1999).

${ }^{30}$ Sandra L. Robinson \& Denise M. Rousseau, Violating the Psychological Contract: Not the Exception But the Norm, 15 J: ORGANIZATIONAL BEHAV. 245, 246 (1994).

31 Id.

32 Cavanaugh \& Noe, supra note 30 , at 324. 
and job ladders that have given employees a stake in the well-being of their firms for the past one hundred years. In the past, internal labor markets were adopted by firms to solve problems of employee motivation, encourage skill acquisition and discourage employee resistance. Therefore, firms need to determine how the new employment system can accomplish these goals.

Today, management's concern for motivation and commitment is more acute than ever. Firms no longer believe they can succeed if employees simply perform their tasks in a reliable but routine manner. Rather, they believe they need something more-they need employees to commit their imagination, energies, and intelligence on behalf of their firm. They want employees to innovate, to pitch in, to have an entrepreneurial attitude toward their jobs, to behave like owners. Current best management practices dictate that they give employees discretion, but they want to ensure that the discretion is exercised on behalf of the firm. Managers believe they need not merely predictable or even excellent role performance, they need "spontaneous and innovative activity that goes beyond role requirements." 33 They want to elicit behavior that goes beyond specific job demands, and gives the firm something extra. Organizational theorists characterize this something extra as organizational citizenship behavior (OCB).

OCB is defined as behavior that goes beyond the requirements of specific role definitions. ${ }^{34}$ It results from affective commitment, i.e. identification with the firm's goals and a desire to do what is best for the organization. ${ }^{35}$ Researchers have found that the presence of OCB is a crucial factor in organizational effectiveness. ${ }^{36}$ Much current human resource policy is designed to encourage $\mathrm{OCB}$, but to do so without making promises of job security. The problem for firms today, then is to elicit in employees what one commentator describes as commitment without loyalty. ${ }^{37}$

33 John R. Deckop et al., Getting More Than You Pay For: Organizational Citizenship Behavior and Pay-For-Performance Plans, 42 ACAD. MGMT. J. 420, 420 (1999).

34 DENNIS W. ORgan, ORganizational CitIZENShIP BEHAVIOR: THE GOOD SOldiER SYNDROME 101-02 (1988).

35 See, e.g., John P. Meyer et al., Organizational Commitment and Job Performance: It's the Nature of Commitment that Counts, 74 J. APPLIED PSYCHOL. 152, 152 (1989); ORGAN, supra note 35, at 105-06.

36 ORGAN, supra note 35, at 9-10; Deckop et al., supra note 34, at 420; see Sandra L. Robinson et al., Changing Obligations and the Psychological Contract: $A$ Longitudinal Study, 37 ACAD. MGMT. J. 137, 149 (1994) (reporting on empirical study that found compliance with psychological contracts to be linked to employee commitment and citizenship behavior).

37 PETER CAPPElli, THE NeW Deal at Work: MANAgng THE Market-Driven WORK FORCE 217 (1999); see also ROSABETH MOSS KANTER, E-VOLVE, 225-26 (2001). 


\section{DISPUTE RESOLUTION IN THE BOUNDARYLESS WORKPLACE}

Another characteristic of the new workplace is that employees expect to have a career that moves around within firms and across firms in what organizational theorists call a "boundaryless career." Individuals' are expected to move frequently across firms and across departmental boundaries within firms, unconstrained by traditional notions of hierarchical progression paths. One scholar writes, "Inside firms in the United States, decentralization, increasing emphasis on cross-functional coordination and teams have blurred previously rigid departmental boundaries. Many American employers have moved to more general job descriptions, emphasizing key values, rather than precise, predetermined duties." 38

Rosabeth Moss Kanter acknowledges that the new employment practices are colliding with "the job insecurity reality" found in American corporations. ${ }^{39}$ She resolves the paradox by advocating that firms offer "employability security" instead of employment security. She says firms should provide lifetime training and retraining opportunities. She claims that this will enable them to attract highcaliber talent, and will give those employees who are downsized other opportunities. ${ }^{40}$ Kanter also urges that firms across countries and across industries develop standard human resources policies on items like fringe benefits, vacations, bonuses, licensing policies, and ensure portability of benefits and skills, to enable workers to function in the new employment setting. ${ }^{41}$

Peter Drucker also tries to confront the paradox of employee motivation in the "no long-term" world. ${ }^{42} \mathrm{He}$ recommends that employees market themselves for their knowledge and their human capital. They should plan to work in networks - for corporations, but not as employees of the corporations. He says upper management needs to stop emphasizing loyalty, and instead learn how to instill trust. 43

Janice Klein, a former G.E. Executive.now M.I.T. Sloan School Professor, also attempts to provide an answer to the paradox. ${ }^{44}$ The task, according to

38 Anne S. Miner \& David F. Robinson, Organizational and Population Level Learning As Engines for Career Transitions, 15 J. ORGANIZATIONAL BEHAV. 345, 347 (1994) (citations omitted).

39 ROSABETH MOSS KANTER, ON THE FRONTIERS OF MANAGEMENT 190 (1997).

40 Id. at 192.

41 Id. at 195.

42 DRUCKER, supra note 23, at 71.

43 Id. at 71-72.

44 Janice Klein, The Paradox of Quality Management: Commitment, Ownership, and Control, in Charles Heckscher, THE POST-BUREAUCRATIC ORGanizaTION: NEW PERSPECTIVES ON ORGANIZATIONAL CHANGE 178 (Charles-Heckscher \& Anne Donnellon eds., 1994). 
Klein, is for managers to "find other means to convince employees that they are in the same boat together." ${ }^{\prime 45}$ She advocates a visible commitment to equity of sacrifice in times of workforce reductions. ${ }^{46}$

We see in these and other writings the elements of the new employment relationship. First, it involves promises of training to enable employees to develop their human capital. Another feature of the new employment relationship is the promise of networks. Not only can employees raise their human capital, they can raise their "social capital" by meeting and interacting with others from other departments within the firm, with customers and suppliers of the firm, and even with competitors. By redefining jobs in competency terms, each employee is a portrayed as a professional in his or her particular area. Some of these newly renamed professionals are "culinary service professionals" (formerly called cafeteria workers), "sales associates" (formerly salespersons), and "executive assistants" (formerly secretaries). They are sent to trade conferences attended by other similar professionals to network and keep up to date.

The new employment relationship also involves compensation systems that peg salaries and wages to market rates rather than internal institutional wagesetting factors. Uniformity in pay is no longer valued, and pay not set for the job, but rather for the individual. The goal of today's compensation systems is to pay each employee according to their distinctive value to the firm. Differential pay is used to reflect differential talents and contributions. Thus, for example, Towers Perrin urges its clients to "reward[ ] results, not tenure, even at the hourly level."47 It also advocates "significantly disproportionate share of all pay programs for high-performing employees," and "differen[t] ... deals based on employee contribution." 48 It acknowledges that these recommendations will create dissatisfaction amongst lower-performing employees, and says:

Top Companies also plan for and achieve higher turnover rates. This strategy is based on the hypothesis that significant pay differentiation provides more motivation for the average and poor contributors to leave as they can get a better deal at other companies which tend to offer higher levels of base pay. ${ }^{49}$

Other features of the new employment relationship are a flattening of hierarchy, the provision of opportunities for lateral as well as vertical movement

45 Id. at 191 .

$46 \mathrm{Id}$.

47 PERSPECTIVES ON TOTAL REWARDS (Towers Perrin, New York, N.Y.), Jan. 2000, available at http://www.towers.com/towers/publications.

$48 \mathrm{Id}$.

${ }^{49} \mathrm{Id}$. 
within and between organizations, and promotion of contact with firm constituents, including suppliers and customers: It also involves the use of company-specific dispute resolution devices.

We can thus make a chart comparing the new to the old employment relationship:

\section{Old Employment Relationship}

- Job Security

- Firm Specific Training

- Deskilling

- Promotion Opportunities

- Command Supervision

- Longevity Linked Pay \& Benefits

- Collective Bargaining \& Grievance

\section{New Employment Relationship}

- Employability Security

- General Training

- Upskilling

- Networking Opportunities

- Micro-level Job Control

- Market-based Pay

- Internal Dispute-Resolution Procedures

\section{THE ROLE OF PROCEDURAL JUSTICE IN THE NEW EMPLOYMENT RELATIONSHIP}

Under the new employment relationship, many of the risks of the firm are shifted to the individual employee. In the past; employees took a risk when they worked in internal labor markets because over time they gained firms-specific skills, and were rewarded with longevity-based pay and benefits, but over time they also became less and less marketable outside their firm. If they lost their job mid-career, they would be practically unemployable. However, the risk was mitigated by the employer's implicit promise of job security.

In the new workplace, employees no longer have an implicit promise of job security. The risk of job loss is thus more serious than ever, and the risk can only be mitigated if employers honor their implicit promises to provide training, networking opportunities, and so forth. Thus to induce employees to take the risk and to obtain employees' cooperation in the new workplace, employers need to make their promises credible. ${ }^{50}$ They need to convince employees that they provide fair treatment and that they will live up to their obligations.

Researchers have found that fair treatment by employers is a crucial factor in generating OCB and affective commitment in today's workplace. Further, they have found that fairness in process is often more important than fairness in

50 Dennis W. Organ \& Mary Konovsky, Cognitive Versus Affective Determinants of Organizational Citizenship Behavior, 74 J. APPLIED PsYCHOL. 157, 162 (1989). 
outcomes-that procedural justice is more important than distributional justice. ${ }^{51}$ Firms therefore seek to develop institutions to offer employers procedural justice.

In the past decade, employers have instituted a wide range of dispute resolution procedures designed to address employee complaints and thus foster high commitment. They have implemented open door policies, ombudsmen, management appeals boards, peer review, mediation, and arbitration. ${ }^{52} \mathrm{~A}$ common characteristic of these dispute resolution techniques is that they utilize decision-makers who are outside the employees' normal chain of command. For example, peer review, in which employees' discipline complaints are heard not by managers but by a panel of the complainant's peers, is one of the fastest growing forms of nonunion dispute resolution. ${ }^{53}$ The new wave of in-house dispute resolution systems is designed to promote procedural justice without reinforcing hierarchy.

The rapid increase in the use of workplace ADR is one way firms attempt to illicit OCB without giving employees a promise of long-term job security. If employees do not believe that they will receive fairness in terms of pay or treatment, they will not be willing to accept the risks attendant to the new (1996).

51 See generally JeRALD GREENBURG, THE QUEST FOR JUSTICE ON THE JOB 32-39

52 Lisa B. Bingham \& Denise R. Chachere, Dispute Resolution in Employment: The Need for Research, in EMPLOYMENT DISPUTE RESOLUTION, supra note 2, at 103-13 (discussing the growth of ombuds, mediation, and arbitration programs amongst nonunion firms); Alexander James Colvin, Citizens and Citadels: Dispute Resolution and the Governance of Employment Relations 126-44 (1999) (unpublished Ph.D. dissertation, Cornell School of Industrial and Labor Relations) (on file with author) (discussing the development of peer review, open door policies, management appeal boards, mediation, and arbitration at TRW in the 1990s). Open door policies are programs that encourage an employee to bring a problem or grievance to a high level manager outside the chain of command. Ombudsmen are specialized corporate officers, independent of management, whose job it is to hear complaints, conflicts, and disputes and reach across status and departmental lines to seek resolution. Management appeals boards are procedures that permit an employee to appeal an objectionable decision of an immediate supervisor to managers in other departments or divisions. Peer review procedures involve dispute resolution by panels of employees who hear and decide specific employee grievances. Id. at 21-26.

53 A recent survey of over 300 firms in the telecommunications industry found peer review procedures in place in 14.4 percent of the firms in the sample, a surprisingly high incidence. Colvin, supra note 52, at 189. At TRW, for example, peer review can be invoked by an employee who wants to challenge a termination or other disciplinary measures. A panel consisting of two managers and three peer employees, under the guidance of a "facilitator" from the human resource department, holds a hearing and decides whether the supervisor correctly applied company policy. Id. at 129-33. In one plant studied, James Colvin found that between 1992 and 1997, 160 employees took cases to peer review, but only ten were successful in overturning a supervisory decision. Id. at 189, 213. 
employment relationship.

Peer reviéw, open door policies, ombudsmen, mediation and arbitration all utilize decision-makers who are managers from other divisions, or co-workers, or outsiders. Thus these arrangements offer a two-fold benefit: first, they make it possible to resolve disputes without reinforcing hierarchy. And second, because the employee's supervisor is not the one who decides the dispute, the process has the appearance of impartiality. The more removed the decisionmaker is from the disputing parties, the more the process and outcome will seem fair.

Thus internal dispute resolution can aid in the functioning of the new boundaryless workplace. Within the universe of ADR mechanisms, there is pressure to move toward those that utilize third-party neutral decision-makers to bolster the appearance of procedural justice. For this reason, we can expect that those dispute resolution processes that utilize outsider decision-makers will proliferate. Mediation and arbitration are the dispute resolution mechanisms that most effectively take decision-making outside the hierarchy and promote neutrality. Hence I predict that we will see an increase in the use of workplace mediation and arbitration for issues involving enforcement of employers' implicit promises in the new employment relationship.

Workplace mediation can be effective when parties have a dispute that stems from miscommunication or when emotional factors or personality traits prevent parties from resolving differences themselves. Mediation can also be helpful to bridge power differentials-to enable those with lesser power in an organization to speak out and to induce those with more power to listen. Many workplace disputes are of this type, and can be resolved in a win-win fashion. ${ }^{54}$ However, when a dispute involves a conflict over a resource allocation decision-whether it concern financial resources or symbolic resources such as job titles, authority, or prestige - a win-win outcome is often not possible. Sometimes a mediator can help identify a potential compromise that each side is willing to make but is unwilling to disclose to the other side. In that event, the mediator may help achieve an acceptable outcome, even if it is not a win-win outcome. However, when mediation is used to resolve a zero-sum dispute between differentially powered individuals, it also poses dangers of hidden coercion for the weaker side. 55

Many disputes in the workplace over alleged breaches of implicit promises

54 See generally ROGER FISHER \& WILLIAM URY, GETTING TO YES: NEGOTIATING AGREEMENT WITHOUT Giving IN (Bruce Patton ed., 2d ed., 1991).

55 See, e.g., Trina Grillo, The Mediation Alternative: Process Dangers for Women, 100 YAle L.J. 1545 (1991); Penelope E. Bryan, Killing Us Sofily: Divorce Mediation and the Politics of Power, 40 BUFF. L. REV. 441 (1992). 
are not about miscommunication, but rather involve zero-sum conflicts over resources. For those disputes, a system of workplace arbitration can give employees confidence that a firm's implicit promises will be kept.

Arbitration and mediation can further the goal of providing procedural justice in the new workplace whether they are part of a pre-dispute arbitration system or whether they are made available on a post-dispute basis. Indeed, if the purpose of having a dispute resolution mechanism is to enable employees to bring complaints of unfairness and thereby foster procedural justice, such mechanisms play this role best if they are initiated voluntarily by an employee at the time a dispute arises.

\section{DISCRIMINATION IN THE BOUNDARYLESS WORKPLACE}

There is a second respect in which we can expect an increase in the use of arbitration for deciding fairness issues in the new workplace. That concerns the changing nature of sex and race discrimination. Much of the civil rights legislation and enforcement efforts of the past three decades have been directed toward eliminating discrimination in employment. The new workplace and the new psychological contract do not eliminate the problem of employment discrimination, but they do change its nature and render many older civil rights strategies and remedies ineffective. In this context, ADR, and particularly employment arbitration, could prove to be an effective anti-discrimination tool.

Title VII enforcement was initially directed at corporate hiring and compensation practices, with the aim of obtaining equal pay and equal access to jobs for women and minorities. But it quickly became apparent that women and minorities needed not simply jobs, but good jobs. They needed access to jobs that offered promotional opportunities, training, job security and benefits-i.e., jobs that were organized as internal labor markets. ${ }^{56}$ Hence Title VII plaintiffs sought not only hiring mandates but also affirmative action to help women and minorities move up the advancement ladders. These Title VII remedies for employment discrimination were well suited to redressing discrimination within firms that utilized internal labor markets.

The widespread use of internal labor markets has contributed to women's and minorities' disadvantaged positions in the labor market throughout much of the twentieth century. Under the internal labor market employment system, employers valued longevity; they wanted to hire employees who would stay on the job a long time. Yet for most of the twentieth century, women, as a group, had a pattern of short job tenure relative to men. ${ }^{57}$ According to economic

56 DOERINGER \& PIORE, supra note 16 , at 133-37.

57 Claudia Goldin found, on the basis of what data was available, that around 1900, 
historian Claudia Goldin, "firms often used sex as a signal of shorter expected job tenure." 58 Thus employers avoided hiring women for jobs in which they valued long tenure. ${ }^{59}$ In this way, the system of job ladders, internal promotions, and limited ports of entry operated to keep women out of the best jobs.

A similar dynamic of discrimination operated with respect to minorities, who were also perceived as having a weak attachment to the labor market. Minority employment opportunities were also curtailed by the overtly racist policies of American employers and unions. For most of the twentieth century, minorities and women were kept out of the core good jobs and relegated to the secondary labor market periphery in which the pay was low, the jobs were dirty, and job security did not exist.

By the 1970s, the equal employment opportunity laws led to improvements in the position of women and minorities in the labor market. However, once the most blatant pay differentials and explicit barriers to hiring women and minorities were broken, those groups continued to be disadvantaged within major corporations. Because jobs were arranged in hierarchical progression, latecomers came in at the bottom and had the farthest to rise. ${ }^{60}$ Also, because they were at the bottom, the latecomers were the first to be laid off in times of cutbacks. Efforts by women and minorities to jump over established arrangements for hierarchical progression generated intense and bitter disputes over affirmative action. White male workers resisted because they felt their psychological contract gave them an entitlement to a certain sequence of advancement, and that affirmative action was thus a violation of their rights.

The new workplace, with its repudiation of implicit promises of long term employment and its rejection of job ladders, holds out the prospect of reversing this century-long pattern of exclusion and disadvantage, and offers the possibility of creating genuine employment opportunities for women and minorities. To the extent that the old employment system locked them out, the demise of that system could be a major improvement. The new employment relationship could spell the end of labor market dualism and the beginning of more egalitarian job structures. However, the new workplace creates new forms of discrimination that

males had almost "three times the duration in current occupation, and one and one-half times the years with current employer" than women. CLAUDIA GOLDIN, UNDERSTANDING THE GENDER GAP 101 (1990).

58 Id. at 116.

${ }^{59}$ LESTER C. THUROW, GENERATING INEQUALITY: MECHANISMS OF DISTRIBUTION IN THE U.S. ECONOMY (1975); Jeremy I. Bulow \& Lawrence H. Summers, $A$ Theory of Dual Labor Markets with Application to Industrial Policy, Discrimination, and Keynesian Unemployment, 4 J. LAB. ECON. 376, 401 (1986).

${ }^{60}$ BLAU ET AL., supra note 27 , at 125-26 (even when women gain access to an occupation, they are often at the bottom of a hierarchy). 
may prove more difficult to change than old ones.

The diffuse authority structure of the new psychological contract makes discrimination hard to isolate or to assess blame. Today's workplace does not have defined job ladders and the criteria for advancement are not clearly specified, so it is difficult for someone to complain that they have been by-passed for advancement because of gender or race. In the boundaryless workplace, everyone makes lateral movements, but some move in circles while others spiral to the top.

In addition, the new nonhierarchical workplace makes lines of authority and power invisible. While ostensibly all employees may increase their responsibilities and enhance their skills, there remains a hidden core of top managers called "decision-makers" who allocate responsibilities and rewards. In the new employment relationship, decision-makers have no clear designation or location on the organizational chart, rendering their decisions to a great extent unaccountable. Thus it is difficult to know to whom to make appeals, with whom to lodge complaints, or how to get access to the centers of power.

Sociologists of organizations note that when there is no visible power structure, the invisible structures rule. In the new workplace, these invisible and secret power structures may turn out to be more remote and impenetrable for women and minorities than the old ones. Responsibility for discriminatory decisions has become difficult to assign and even more difficult to remedy. Title VII remedies, such as decrees requiring employers to move women and minorities up job ladders, are not useful to redress the new forms of employment discrimination. Thus, new theories of liability and new remedies need to be designed.

A related problem for women and minorities in the new workplace stems from the trend toward delegating major employment decisions to peers. Sociologists of work have highlighted the role of peer groups, cliques, and networks in perpetuating sex and racial segregation in employment. ${ }^{61}$ Workplaces are social organizations in which people interact with each other to learn the tricks of the trade, share necessary information, assist in tasks, and coordinate performance. The need for cooperation and teamwork makes it difficult for employers to incorporate women and minorities when there is resistance from incumbent white males. The phenomenon of women being shunned, ignored, and frozen out of the loop when they enter predominately male workplaces has been well documented. ${ }^{62}$ Many first-person accounts attest to the

61 See, e.g., MARK S. GRANOVETTER, GETTING A JOB: A STUDY OF CONTACTS AND CAREERS 45-48 (1974); JERRY A. JACOBS, REVOlVING DOORS: SEX SEGREGATION AND WOMEN'S CAREERS 181-82 (1989).

62 See, e.g, Rosabeth MOSS KANTER, MEN AND WOMEN OF THE CORPORATION 207 
power of workplace cliques to exclude, demoralize, stigmatize, or otherwise disempower those who are targeted for exclusion. ${ }^{63}$ Clique members ordinarily use the tools of ostracism, belittlement, verbal harassment, innuendo, nefarious gossip, and shunning - tools that defy efforts to identify or remedy. And often the targets are newcomers, atypical employees, those who are not part of the old crowd-i.e., women and minorities. Reports of such conduct are becoming increasingly prevalent. ${ }^{64}$

The new workplace exacerbates the age-old problem of cliques because it involves empowering peer-based decision-making. For example, several organizational theorists urge firms to use peer groups to decide important issues such as hiring, evaluation, job allocation, and pay, and to resolve disputes. ${ }^{65}$ While peer-based decision-making may work well in some situations, it can also promote cliquishness and lead to patronage systems, bigotry, and corruption. In such a workplace, women and minorities could again find themselves excluded. The growing popularity of peer review procedures for deciding disciplinary infractions could similarly reinforce in-groups and exacerbate the exclusion of newcomers.

For these reasons, women and minorities need to find strategies to combat the dangers that the new workplace poses. That is where arbitration of fairness norms could play a constructive role. A few legal scholars have recently considered the problem of clique-based discrimination and tried to devise legal approaches. Vicki Schultz has focused on the problem of workplace cliques sabotaging the work efforts of women who enter traditionally male workplaces. ${ }^{66}$ She recounts the disabling impact of such conduct on women and proposes that such gender-motivated but non-sexual harms be actionable under Title VII. She argues that the definition of sexual harassment under Title VII be broadened to include not only affronts that embody some form of explicit sexuality but also any "conduct designed to undermine a woman's competence." ${ }^{367}$ In cases where it is difficult to establish whether the challenged conduct is based on gender, she proposes a presumption that it is so based in contexts where women work in

(1977); JACOBS, supra note 62, at 181-82.

63 Vicki Schultz, Reconceptualizing Sexual Harassment, 107 YALE L.J. 1683, 1704 (1998).

${ }^{64}$ Id. at 1694-95; David C. Yamada, The Phenomenon of "Workplace Bullying" and the Need for Status-Blind Hostile Work Environment Protection, 88 GEO. L.J. 475 (2000).

65 See, e.g., EDWARD E. LAWLER III, HIGH-INVOLVEMENT MANAGEMENT: PARTICIPATION STRATEGIES FOR IMPROVING ORGANIZATIONAL PERFORMANCE 191-233 (1986).

66 Schultz, supra note 64, at 1769.

67 Id. at 1769. 
traditionally male jobs. ${ }^{68}$

David Yamada has written about the problem of abusive supervisors who undermine a particular worker's morale and confidence. ${ }^{69}$ His discussion is not limited to gender or race-based harassment claims, but to all types of bullying by supervisors. He proposes that there be a new cause of action called the "Intentional Infliction of a Hostile Work Environment"70 which would make an employer liable for "intentionally subject[ing] the plaintiff to a hostile work environment."71 While Yamada's proposal is not limited to gender or racial discrimination claims, it is an attempt to address the kinds of pernicious conduct that are particularly problematic for women and minorities in the new workplace.

Both Schultz's and Yamada's proposals are bold and creative efforts to reach beyond existing discrimination law and address heretofore unnamed workplace injustices. The virtue of their proposals is that they identify, name, define and constrain some of the forms of harmful conduct that seem to be increasing in the workplace. However, neither proposal addresses all the problems women and minorities face in the boundaryless workplace. They both propose theories of liability to constrain actions by supervisors that intimidate, harass, sabotage, or otherwise bully a subordinate. But as the above discussion highlighted, the most serious forms of discrimination in the new workplace are often not the result of employer conduct but of co-worker conduct.

It is difficult to imagine a form of workplace discrimination law that would place sanctions on workers who acted so as to undermine, marginalize, demoralize, or otherwise incapacitate their co-workers. Current Title VII law only reaches co-workers when the co-worker harassment is conduct that the employer knew or should have known of, and to which the employer failed to take remedial measures. ${ }^{72}$ This is because employment discrimination laws prohibit those who have authority in the employment relationship from exercising their power in a discriminatory fashion. ${ }^{73}$ They do not provide a generalized code of workplace civility. ${ }^{74}$

A better approach to employment discrimination that could prevent the new workplace from degenerating into a bevy of cliques and patronage networks and, at the same time, address the problems of invisible authority and lawlessness would be to encourage firms to develop meaningful dispute-resolution systems

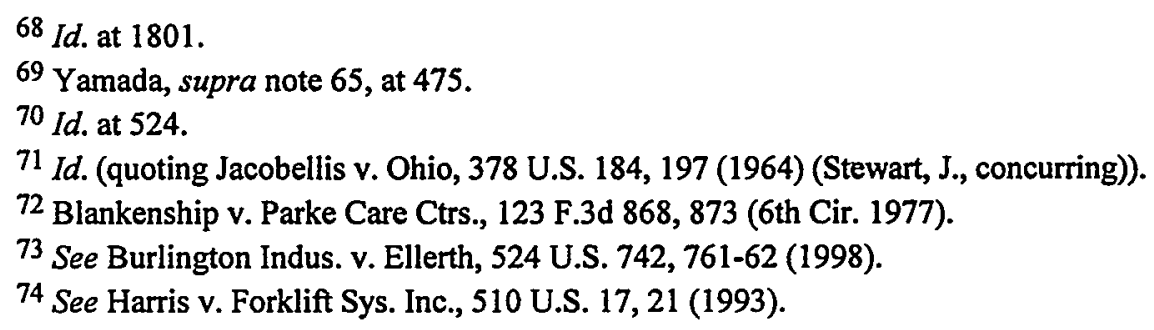


to address worker-co-worker as well as worker-supervisor complaints. These systems would have to utilize external decision-makers to hear allegations of coworker as well as supervisor bullying. By bringing outside neutrals to adjudicate these types of disputes, such a system could inject an external standard of fairness that would displace, and transform, the rule of the clique. Some corporations have already designed dispute resolution systems that address both grievances between the employee and the firm and disputes between employees. If properly structured, internal disputes resolution systems could help counteract the development of workplace fiefdoms and cliques, redress abuses of hidden authority and bring external norms to the workplace.

The Supreme Court has recently given a boost to the development of such systems in its decisions in Faragher v. City of Boca Raton ${ }^{75}$ and Burlington Industries v. Ellerth. ${ }^{76}$ In those cases the Court held that employers could avoid liability for sexual harassment if they have internal disputes procedures in place to deal with harassment claims and the complaining employee unreasonably fails to utilize them. If the court extended the reasoning to co-worker claims, then employers would have a powerful incentive to utilize arbitration for these new types of discrimination claims.

\section{WORKPLACE ARBITRATION FOR THE NEW WORKPLACE}

I have advocated the use of arbitration to address two types of problems that arise in the boundaryless workplace: employer breaches of the new psychological contract and new forms of employment discrimination. It is necessary to consider what such a system would look like and what should be the legal framework in which such a system operates. By understanding employment arbitration from a normative rather than a technical perspective, the problem becomes one of designing a system that reflects and promotes internal fairness norms without depriving employees of external substantive rights.

To be effective in the new workplace, arbitration would have to embrace disputes between co-workers as well as disputes between employees and employers. Liability standards could be derived from internal fairness norms generated within the workplace as interpreted and applied by an outside arbitrator. The outside arbitrator would provide a check on the possibility of tyranny and capture by insider cliques.

It also would be important that a workplace arbitration system ensure the participation of both the employer and employee in the process. The rights of employees or their representatives to equal participation in the selection of

75 Faragher v. City of Boca Raton, 524 U.S. 775 (1998).

${ }^{76}$ Burlington Indus., 524 U.S. 742. 
arbitrators should be baseline requirements for a self-regulatory system of nonunion arbitration. It is not sufficient to give employees an ability to select names from a list of arbitrators pre-selected by the employer.

Workplace arbitration would be a supplement to, but not substitute for, statutory rights. Arbitration of customary norms should be used to fill the injustices, not to substitute for other statutory or express contractual rights. Thus arbitration awards should be subject to judicial review on issues of law, but not for interpretation or application of norms. De novo judicial review for arbitral rulings on issues of law is necessary to ensure that Title VII and other employment laws are applied to the workplace.

Under this proposal, workers with claims based upon violations of customary workplace norms could choose to submit them to their workplace's arbitration procedure. Because claims based on workplace fairness norms often do not give rise to legal claims, it is reasonable for the courts to defer to such norm-based claims to arbitration. But a worker with a claim based on a legal right, whether contractual or statutory, should retain the option of bringing the dispute to a judicial forum. If the worker selected arbitration, the arbitral decision would be binding on issues of fact and on issues of law-of-the-shop norms. However, it would be appealable on issues of law. In order to preserve the right of a judicial appeal, a record would have to be made and a written opinion rendered. Also, under this proposal, the worker should be entitled to engage in limited discovery and to have an attorney represent him or her in order to ensure adequate development of facts and presentation of the case. The resulting award would be final and binding only on issues of fact or norms. Local norms, however, could not trump legal rights.

The foregoing proposal provides a mechanism for resolving disputes over alleged breaches of implicit contractual rights and discrimination claims in the new workplace. It is a mechanism that would enable employers to make credible commitments in the new employment relationship, enable employees to monitor and contest perceived incidents of unfairness, and enable women and minorities to obtain redress for bullying, shunning, harassing, and other conduct that undermines their employment prospects. I propose that this type of arbitration be termed "workplace arbitration" rather than "employment arbitration," because it vindicates not the values of subordination but the value of fairness within a shared normative community.

Workplace arbitration, as proposed, would cost more to implement than most nonunion arbitration systems currently do because it calls for a transcript, a reasonably full hearing, and a written opinion. However it also offers employers an informal procedure that has a high likelihood of resolving day-to-day disputes over fairness norms - the types of disputes that are the most likely to generate illwill, produce low morale and hinder production. The proposal also provides a 
relatively expeditious fact-finding procedure that could stave off many lawsuits and greatly shorten others. Employment discrimination suits are factually dense. To the extent that documentary evidence and credibility assessments can be determined in an arbitral review setting, employers and employees can often be spared lengthy and expensive litigation. This type of arbitration would also give employees an opportunity to air complaints about the unfairness of a decision in the workplace or raise concerns about management practices. Currently, many employees recast claims about perceived instances of management unfairness as legal claims of discrimination in order to avail themselves of the only recourse available. Workplace arbitration could provide an alternate route to seek redress for violations of the customary norms of the workplace. That is, it could offer employees an enhanced degree of fairness in'employment while also reducing the amount of litigation faced by employers.

\section{CONCLUSION}

Despite the many well-founded criticism of employment arbitration that have been raised by judges and scholars since Gilmer was decided, the use of alternative dispute resolution in the workplace is expanding at a fast pace. At this point, as many workers are covered by nonunion arbitrations systems as are covered by collective bargaining agreements. ${ }^{77}$ In addition, in light of changes occurring in the employment relationship, we can predict that arbitration will be an increasingly important source of justice to both employers and employees. This article has attempted to define the positive role that arbitration could play in the emerging workplace. It has also proposed a system of workplace arbitration that would utilize the arbitral forum to promote what arbitrators do best-to serve as an external force to decide disputes on the basis of the internal fairness norms of a self-regulating community, within the context of the norms of the larger community. Workplace arbitration, as proposed herein, would balance the internal law of the shop with the external law of the land. Thus it would enable employers to make credible commitments to provide fair treatment and at the same time give employees confidence that they were not forced to check their employment rights at the door. Employment arbitration, as herein proposed, could thus be an important mechanism for ensuring dignity, equity, and fairness in the new boundaryless workplace.

77 Stone, Employment Arbitration, supra note 3, at 27. 
